Volume 8

$5-1-2014$

\title{
Justice After Genocide: Impunity and the Extraordinary Chambers in the Courts of Cambodia
}

Wendy Lambourne

Centre for Peace and Conflict Studies, University of Sydney, Australia

Follow this and additional works at: https://digitalcommons.usf.edu/gsp

\section{Recommended Citation}

Lambourne, Wendy (2014) "Justice After Genocide: Impunity and the Extraordinary Chambers in the Courts of Cambodia," Genocide Studies and Prevention: An International Journal: Vol. 8: Iss. 2: 29-43. DOI:

http://dx.doi.org/10.5038/1911-9933.8.2.5

Available at: https://digitalcommons.usf.edu/gsp/vol8/iss2/7

This Articles is brought to you for free and open access by the Open Access Journals at Digital Commons @ University of South Florida. It has been accepted for inclusion in Genocide Studies and Prevention: An International Journal by an authorized editor of Digital Commons @ University of South Florida. For more information, please contact digitalcommons@usf.edu. 


\title{
Justice After Genocide: Impunity and the Extraordinary Chambers in the Courts of Cambodia
}

\author{
Wendy Lambourne \\ Centre for Peace and Conflict Studies, University of Sydney, Australia
}

\begin{abstract}
After nearly 40 years, some of the key leaders of the former Khmer Rouge genocidal regime are facing trial at the Extraordinary Chambers in the Courts of Cambodia (ECCC). This paper explores the challenges and opportunities facing the ECCC in its pursuit of justice and accountability for the atrocities committed by the Khmer Rouge against the Cambodian people. It concludes that, despite the political controversies and resource constraints affecting the court in fulfilling its mandate to end impunity, victims and survivors of the Pol Pot era may still benefit psychologically from the long-overdue official acknowledgement of their suffering and the opportunity for younger generations to learn the truth of what happened. Some justice could indeed be better than none in the quest for healing and reconciliation at the individual and community level. This process may be undermined, however, if the prevailing culture of "small impunities" and the need for political and socioeconomic justice, along with psychosocial support, are not addressed.
\end{abstract}

Keywords: Cambodia, genocide, justice, reconciliation, truth, accountability, Khmer Rouge

\section{Introduction}

When I first travelled to Cambodia to conduct field research in 1999, I discovered that the lack of accountability for the former Khmer Rouge leaders responsible for the genocide of 1975-1979 was seen as the biggest impunity and the root of all the smaller impunities in Cambodian society at the time. ${ }^{1}$ However, despite the subsequent creation of the Extraordinary Chambers in the Courts of Cambodia (ECCC) 25 years after the Pol Pot regime was deposed, this culture of impunity persists. On 12 November 2013, a female bystander was killed during a violent crackdown by riot and military police against demonstrating garment factory workers in Phnom Penh. The Cambodian Human Rights Action Committee (CHRAC) responded by highlighting the culture of impunity, which continues to prevail in Cambodia:

Impunity cannot be allowed the reign in Cambodia. With Chhouk Bandith free and still no investigation into the death of Mr. Mao Sok Chan, Cambodia's claim to be a country that respects rule of law lacks any credibility. $^{2}$

This paper explores the challenges of ending impunity and pursuing justice after genocide in Cambodia, including an analysis of the historical and political context as well as the multiple justice needs and priorities of Cambodians. Drawing on field research conducted in Cambodia in 1999 and 2009, ${ }^{3}$ it concludes that, despite accusations of corruption and political manipulation, the ECCC could still contribute to peace and reconciliation because of the potential symbolic and psychological benefits for survivors of having their suffering officially acknowledged at last. What is missing in Cambodia is a greater commitment to political and socioeconomic justice, along with psychosocial support and implementation of the rule of law, which could underpin a more sustainable peace at individual, community and national levels.

\section{Historical and Political Context}

Cambodia was once a great nation covering much of Southeast Asia, with its own distinct Khmer culture influenced by India's two great religions, Hinduism and Buddhism. Culminating in the Angkor dynasty, the glorious Khmer Empire lasted from the seventh to the thirteenth century, after which it was progressively weakened by invasions from its neighbors Siam (now Thailand) and Vietnam. It was this glorious past that Pol Pot and his cohort were inspired to recreate for the people of Democratic Kampuchea by wiping out all foreign influences including the Vietnamese that were seen as undermining the pure Khmer identity.

In 1863 Cambodia became a French protectorate and then colony until 1953, when King Norodom Sihanouk regained the country's independence. ${ }^{4}$ After seventeen years of relative peace as an independent country, Cambodia became drawn into the Vietnam War. In 1969 the U.S. Air Force had begun secretly bombing Cambodia in an effort to eliminate the Vietnamese communist bases, and the anti-Vietnamese Lon Nol government took power in Cambodia (renamed the Khmer Republic). Sihanouk, now in self-imposed 
exile, forged a coalition with the communist-backed Khmer Rouge who fought a civil war with the U.S.backed Lon Nol government. In 1975 the United States withdrew from Vietnam, Phnom Penh fell to the Khmer Rouge, and the Cambodian people were subjected to three years of the brutal Khmer Rouge regime led by Pol Pot (Democratic Kampuchea) under which an estimated 1.67 million Cambodians (approximately $25 \%$ of the population) died..$^{5}$

The Khmer Rouge regime started its reign of terror by forcibly evacuating all inhabitants from the capital city, Phnom Penh, and other towns to rural areas as part of its agrarian revolutionary plan. The systematic and carefully planned regime of terror, torture, hard labor and starvation was aimed at establishing a racially pure and independent Khmer state uninfluenced by the West or the trappings of wealth and privilege. The victims were identified by a political ideology that characterized the enemy as people of the elite or middle class: the educated, city dwellers, professionals, those who could write, wore glasses or spoke foreign languages. These enemies were often killed outright.

In addition to the economic and physical deprivations there was a complete denial of all social and cultural rights. Foreign and minority languages were banned; schools and hospitals were closed; the labor force was conscripted; families were separated; religions and folk cultures were destroyed, including the majority Buddhist religion. ${ }^{6}$ The Constitution of Democratic Kampuchea promulgated in January 1976 failed to guarantee any human rights and abolished private property, organised religion and family-oriented agricultural production, and the four-year economic plan drafted in 1976 said nothing about leisure, religion, formal education or family life. ${ }^{7}$

The mass killing that occurred under the Pol Pot regime is generally seen as politically and socioeconomically motivated, with particular ethnic and religious groups that were specifically targeted and almost totally eliminated, including Buddhists, the Vietnamese, Chinese and minority Cham Muslims. ${ }^{8}$ It was a communist-inspired class struggle taken to extremes and augmented by identity-based violence and killing. I have argued elsewhere that the extent of hatred of the Vietnamese and mission of purity extolled by Pol Pot and the Khmer Rouge indicates an identity-based or ethnic motive, rather than simply political ideology, that reinforces the label of genocide even though the majority of killings did not strictly fall under the Genocide Convention definition. ${ }^{9}$

Following border incursions and a previously failed full-scale invasion, Phnom Penh fell to the Vietnamese in January 1979, the Khmer Rouge retreated to the Thai border and the country's name was changed to the People's Republic of Kampuchea (PRK). The international community condemned the Vietnamese invasion, and the Pol Pot regime continued to be recognized by the UN as the official government of Cambodia. In 1989 the Phnom Penh government with Hun Sen as Prime Minister renounced communism and changed the country's name to the State of Cambodia, and the Vietnamese withdrew. Elections in May 1993 under the supervision of the United Nations Transitional Authority in Cambodia (UNTAC) resulted in a coalition government with Prince Ranariddh (Sihanouk's son) and Hun Sen (leader of the pro-Vietnamese Cambodian People's Party) as co-prime ministers. However, following a coup against Ranariddh and his other opponents in July 1997, Hun Sen declared himself sole Prime Minister of Cambodia. The Cambodian People's Party has remained in power since then with Hun Sen as Prime Minister.

\section{Accountability for Genocide?}

In the wake of the genocidal Pol Pot regime, there were no significant or effective official public processes of accountability implemented in Cambodia, despite the numerous initiatives proposed by the international community and Cambodian government. ${ }^{10}$ Nor were there any official international acts of condemnation or prosecution. The People's Revolutionary Tribunal of Khmer Rouge leaders, Pol Pot and Ieng Sary, held in Phnom Penh in August 1979, imposed a sentence of death in absentia for the crime of genocide, but this was not recognized internationally because of due process objections to the trial procedures and the diplomatic isolation of the PRK regime, and the sentence was never carried out. ${ }^{11}$ According to Hammer and Urs, by turning the trial into a tool of propaganda, the PRK 'co-opted justice in the name of politics.'12

The international community was at first deterred by Cold War constraints, political priorities, and respect for state sovereignty from condemning the atrocities of the Pol Pot regime. Once the Cold War was over, the international community was still constrained by the legacy of Cold War geopolitical alliances, as well as fears that they might also be held to account for their role in supporting the Khmer Rouge. The United Nations played a significant role in rebuilding peace in Cambodia, but the issues of justice and reconciliation 
were not addressed in the Paris Peace Agreement of October 1991. The final agreement did not preclude the Khmer Rouge from participating in the Cambodian elections, nor did it prevent former officials of the Khmer Rouge associated with the genocide from holding office in the future. ${ }^{13}$ Hammer and Urs attribute the failure to pursue justice for the Khmer Rouge during these two periods to the "politics of ideology" (1975-89) and the "politics of reconstruction" (1989-1996). ${ }^{14}$ As pointed out by Etcheson: "issues of transitional justice and accountability for serious violations of international humanitarian law are always intensely political." 15

The Khmer Rouge, meanwhile, were able to maintain their strongholds in towns such as Pailin near the Thai border. They continued their guerrilla activities with impunity for the next 20 years until the organisation was formally disbanded in 1998 after the death of Pol Pot and the defections of two former Khmer Rouge leaders, Khieu Samphan and Nuon Chea. Ieng Sary had defected after being granted amnesty in 1996. In March and May 1999, the Cambodian government arrested two other former Khmer Rouge leaders, Ta Mok and Duch. Both men faced charges of treason, torture, murder and genocide as well as breaking the 1994 law banning the Khmer Rouge. ${ }^{16}$ Ta Mok died in 2006, but Khieu Samphan, Nuon Chea, Ieng Sary and Duch, along with Ieng Thirth, survived to be indicted by the ECCC. ${ }^{17}$

\section{The Extraordinary Chambers in the Courts of Cambodia}

Following several years of negotiations, the UN and Cambodian government finally signed a draft agreement on 6 June 2003 for the establishment of a tribunal to try the surviving former Khmer Rouge leaders, but it took another two years for funding arrangements to be negotiated and the final form of the hybrid tribunal to be agreed. ${ }^{18}$ The ECCC was finally established in November 2005 and by May 2006 the judges and prosecutors had been appointed. The ECCC has been characterized as a hybrid tribunal because of the mix of international and Cambodian judges, but in reality it has operated as a national Court with international participation. The United Nations half of the Court has found itself with a limited capacity to control the Court's functioning, and has seemed impotent to prevent corruption and political influence, if not interference.

The crimes being prosecuted by the Court include homicide, torture and religious persecution as defined in Cambodian domestic law; genocide as defined by the 1948 Genocide Convention; crimes against humanity as defined by the Rome Statue of the International Criminal Court; war crimes defined as grave breaches of the Geneva Conventions of 1949; and crimes against cultural property defined by the Hague Convention of $1954 .{ }^{19}$

The ECCC is instituting a unique feature of international or hybrid tribunals - the opportunity for victims to take complaints to the tribunal as civil parties. In addition to being able to appear as witnesses, victims of crimes, which fall under the jurisdiction of the court, are able to lodge complaints with the ECCC, to be represented by prosecuting lawyers and to claim collective and moral reparations. ${ }^{20}$ In the beginning, civil parties were individually represented, but this was later changed to improve efficiency by requiring civil parties to be collectively represented.

On 17 February 2009 I attended the first day of the initial hearing of the first trial at the ECCC, popularly known as the Khmer Rouge Tribunal (KRT). There were crowds of foreigners and Cambodians, lining up to ensure their place in the courtroom for this historic occasion, to see Comrade Duch (Kaing Guek Eav) face charges for crimes committed whilst he was in charge of the notorious Tuol Sleng prison S-21 during the Khmer Rouge regime. In Case 001, Duch was charged with crimes against humanity, grave breaches of the Geneva Conventions of 1949, and the domestic crimes of homicide and torture. During the trial, Duch confessed, admitted responsibility and sought forgiveness for his role in the running of S-21 and the crimes that were committed there. This is an excerpt from one of Duch's apologies from 16 September 2009:

Please allow me to offer my apology to all the victims who were subjected to the utmost suffering at this place [S-21] until the day they lost their lives or until 7 January 1979. I would like to offer my apology to the victim's families who have been living in pain for the past 33 years without their beloved family members and who have not yet obtained justice. ${ }^{21}$

The verdict of Case 001 was announced in July 2010 and Duch was sentenced to 35 years imprisonment, reduced to 19 years because of time already served and compensation for prior illegal detention. Furthermore, most of the civil parties' claims for reparations were rejected because Duch was found to be indigent. However, following appeals, the decision was made in February 2011 to increase Duch's sentence to life 
imprisonment for overseeing the deaths of approximately 15,000 people. The Supreme Court Chamber also decided on appeals from civil parties related to the Trial Chambers' ruling on their requests for collective and moral reparations, and affirmed the Trial Chamber's decision to compile and post on the ECCC website all statements of apology and acknowledgement of responsibility made by Duch during the course of the ECCC proceedings. The Court's first reparations award issued in May 2012 also provided for the names of the civil parties and immediate victims to be listed in the final judgement. Other collective reparations sought by the victims included access to free medical care and funding for educational programs about S-21 and the Khmer Rouge, as well as erection of memorials and pagoda fences.

The other four surviving senior Khmer Rouge leaders - Nuon Chea, Khieu Samphan, Ieng Sary and his wife, Ieng Thirith - were then to be tried together in a group trial as Case 002, which commenced in November 2011. The defendants were indicted on charges of crimes against humanity, grave breaches of the Geneva Conventions of 1949 and genocide. The case includes charges of forced evacuations, forced marriage, torture, executions, enslavement and genocide against ethnic Vietnamese and Cham Muslim populations. However, in light of the complexity of the case and considering the elderly, frail condition of the accused, the Court decided to proceed with the case in a series of mini-trials, starting with charges associated with the forced evacuations of the population of Phnom Penh and other major urban centres. The charges for this stage of Case 002 were later amended to include the execution of Lon Nol leaders and loyalists at Toul Po Chrey immediately after the Khmer Rouge took power in April 1975. But the more significant charges for the victims relating to enslavement, forced marriage, torture, executions and genocide will not be considered until subsequent mini-trials.

Known as Case 002/01, the first mini-trial concluded in November 2013, but only after one of the accused, former Foreign Minister Ieng Sary, had died of a heart attack in March 2013. His wife, former Minister of Social Affairs, Ieng Thirith, was judged unfit to stand trial because of dementia in 2012. Therefore only two senior Khmer Rouge leaders, 87 year old 'Brother No. 2' Nuon Chea and 82 year old former Head of State, Khieu Samphan, were tried and remain in custody awaiting the verdict which is expected in the second quarter of 2014. The timing of the second mini-trial, Case 002/02, is in question because of a lack of funding and the potential need to appoint another set of judges if it is to commence before the verdict is reached on Case 002/01.22 On both counts, there are justifiable fears that the accused may not survive to hear the verdict of Case 002/01, far less live long enough to be tried and convicted in Case 002/02. This would mean that no former Khmer Rouge leaders are, in the end, tried and found guilty of genocide. This lack of prosecution for genocide might not be easy for Cambodians to accept, given that the term genocide has been used since 1979 to describe the atrocities of the Pol Pot era. On the other hand, some evidence suggests that the details of the charges are not as important for the survivors as simply seeing their former leaders in court and behind bars.

According to Youk Chhang, genocide survivor and Director of the Documentation Center of Cambodia (DC-Cam), the fact that the senior Khmer Rouge leaders have been arrested and put on trial is profoundly significant. He suggests that the legal arguments mean little to people, but that seeing their former leaders incarcerated during the past six years has been essential: "for the public, they are [already] convicted". He adds that even if they die in jail, they will be regarded as having been "cursed by their bad karma". 23

On the other hand, Cambodians are critical of the time the trials are taking. For example, a female survivor whom I interviewed in Kampong Thom in January 2009 wondered 'why they don't make the hearings quickly, why do they keep delaying?'. It is especially hard for the victims to understand and accept the processes involved in ensuring the right to a fair trial and the presumption of innocence, the processes required to prove guilt and the money, time and energy spent on defending Nuon Chea and Khieu Samphan when the media has already "established the facts we "know"'. 24 Why should it take so long to come to a verdict when the crimes of the Khmer Rouge have been so thoroughly documented by genocide scholars and others including DC-Cam? For example, following the closing hearings of case 002/01, Kem Chem, aged 60 from Pursat Province, said:

I cannot agree with Nuon Chea when he says that victims are mistaken. We all know how much we suffered throughout 3 years, 8 months and 20 days. We need the truth and the respect to the victims. I think that the KR Tribunal is making true reconciliation. When I attend the court, it feels like anger is released in from my heart. I have relatives who were killed in the KR regime. I wish the court would expedite the trial so that the accused have a sentence as soon as possible. ${ }^{25}$

According to my research, what may be more significant than convictions in judging the impact of the Court is the extent to which Cambodians get an answer to the ever-present question of 'Why did Khmer 
kill Khmer?' Trials are not normally the best method of finding the truth, yet survivors have shown a strong interest in hearing the accused speak about what occurred during the Pol Pot era, with the hope of finding out what happened to their family and hearing some kind of truth which could contribute to justice, reconciliation and healing. ${ }^{26}$ This is also true of some of the young people who want to understand their country's history. For example, Leng Samnang, a 21 year old university student interviewed after the closing hearings of Case 002/01, said:

I believe it is important for every Cambodian to know the truth about this horrendous time in our story. This is why I am here. I want to know the KR tribunal. I want to understand the Case 002/01 and hear Nuon Chea and Khieu Samphan. ${ }^{27}$

Both Nuon Chea and Khieu Samphan have disappointed in this regard. Whilst they apologised to the people of Cambodia during the trial proceedings in May 2013, this was not an acceptance of responsibility for the crimes of which they are accused. Rather, they apologised that the Khmer Rouge revolution was "a complete disaster" and maintained that they did not have any real power and were unaware of the suffering of the people. The survivors were further disappointed when both of the accused refused to testify further because they had lost confidence in the Court providing a fair trial, and when, in their lengthy closing statements, the former Khmer Rouge leaders continued to distance themselves from responsibility:

'It is easy to say that I should have known everything, I should have understood everything, and thus I could have intervened or rectified the situation at the time,' Khieu Samphan defiantly told the court. 'Do you really think that that was what I wanted to happen to my people?' 'The reality was that I did not have any power', he said. Nuon Chea also defended his actions, saying he never ordered Khmer Rouge cadres 'to mistreat or kill people to deprive them of food or commit any genocide. ${ }^{28}$

Nuon Chea did, however, unlike Khieu Samphan, accept "moral responsibility" for the deaths: "I would like to sincerely apologize to the public, the victims, the families, and all Cambodian people," he said. "I wish to show my remorse and pray for the lost souls that occurred by any means" during the Khmer Rouge rule. Nuon Chea's apology evoked this response from one of the many survivors who crowded the courtroom for the final day of hearings in Case 002/01:

'He is just trying to cheat the court so that he can be freed,' said Bin Siv Lang, a 56-year-old woman who lost 11 relatives during the Khmer Rouge rule. 'If he issued no orders to kill people, his subordinates would not have killed. ${ }^{29}$

Bin Siv La, from Porsat province, went on to say that she expected Nuon Chea to be found guilty and to be hanged for the suffering he had caused her and her family.

Nuon Chea's defense lawyer argued that the evacuation of Phomn Penh 'was done for military and practical reasons, and lacked criminal intent', while the former Khmer Rouge leader claimed that Cambodians left the cities of their own free will and that the evacuation was a "humane act" designed to protect them from impending US bombings and the threat of starvation. ${ }^{30}$ These claims are unlikely to provide the truth sought by survivors for whom these accounts do not match their experience of the inhumane treatment they received. Nuon Chea went on further to blame the Vietnamese as well as unruly subordinates and differing factional interests among zone and district commanders for the suffering his regime caused. ${ }^{31}$ Khieu Samphan similarly claimed that his actions were based on good intentions: "My political conscience at that time, given the reality on the ground, whatever I did was to protect the weak; to uphold and respect their fundamental rights and to build a Cambodia that was strong, independent and peaceful.” Both men continued to maintain their innocence, and the National Co-Prosecutor Chea Leang called for the maximum penalty of life imprisonment for the alleged crimes against humanity committed by the accused.

Also at the closing hearings, lawyers for the civil parties outlined thirteen proposed reparation projects to be awarded if the accused are found guilty. The proposed projects were divided into three main categories: remembrance and memorialization, including establishment of an official remembrance day and memorial sites; rehabilitation, such as testimonial therapy and self-help groups implemented by TPO; and documentation 
and education, including establishment of a Peace Study Centre and mobile exhibition project. ${ }^{32}$ If awarded, these reparations could contribute significantly to the psychosocial, symbolic and preventive aspects of transitional justice which can support individual and community, and hence national, peace and stability. ${ }^{33}$

The survivors whom I interviewed in Cambodia in 2009 were mostly happy with the idea of collective reparations to provide services for local communities, although one male survivor did argue that because of the disability he suffers as a result of torture by the Khmer Rouge that he should receive individual compensation. He was particularly critical and bitter about the ECCC process and its likely value for him personally. Another survivor, a woman who had lost all her family during the Khmer Rouge time whom I interviewed in Kampong Thom, indicated "I think I would be peaceful in my mind if I get any support if a road to my house would be built". So far, little in the way of substantive reparations has been provided by the ECCC, but preparations for implementation of reparations projects from Case 002/01 is underway with the participation of civil parties and ongoing efforts to secure sufficient funding. ${ }^{34}$

\section{Justice Compromised?}

The ECCC has faced significant challenges in obtaining sufficient funding, overcoming delays in its startup and ongoing operations, upholding standards of fairness, and prosecuting crimes committed more than 30 years ago. Even if it manages to meet these legal and operational demands, questions remain as to the ECCC's ability to satisfy the goals of accountability, truth and justice, and most importantly, an understanding of why such crimes were committed by Cambodians against their own people. ${ }^{35}$

The temporal jurisdiction of the ECCC means it cannot prosecute crimes perpetrated by the Lon Nol government which preceded the Pol Pot regime, nor address the role of foreign governments in aiding and abetting the Khmer Rouge, nor crimes allegedly committed in subsequent years by Hun Sen and the Vietnamese-installed government. Its ability to end the culture of impunity still prevalent in Cambodia is therefore only partial. The personal jurisdiction of the ECCC is limited to bringing to justice "senior leaders of Democratic Kampuchea and those who were most responsible for the crimes and serious violations". ${ }^{36}$ It could not try those Khmer Rouge leaders who had already died, including Pol Pot and Ta Mok, and of the five key Khmer Rouge leaders brought to trial, one has since died and one has been deemed unfit to stand trial, leaving one convicted in Case 001 and only two remaining to face the charges in Case 002.

Efforts to open a third case and try some lower level leaders have been thwarted by the Cambodian government and national ECCC prosecutors, although investigations are continuing in the hands of the international prosecution. Some have argued that it would be better to use the additional resources for alleviating poverty rather than an expensive tribunal, which will try only a few people. ${ }^{37}$ Kek Galabru, President of LICADHO, has asked whether such a tribunal would "bring justice to the Cambodian people and to fight against the culture of impunity? Or is it just a show trial for the international community, especially to appease the donors?" ${ }^{38}$ According to Maguire, some Cambodians had given up on punishment and 'they simply seek acknowledgment. ${ }^{39}$

Faith in the ECCC to provide truth and acknowledgement by the former Khmer Rouge leaders is likely to be misplaced, however, except in the case of Duch who confessed and sought the forgiveness of the Cambodian people for his role in the torture and killings that took place at Toul Sleng. By contrast, as discussed above, Nuon Chea and Khieu Samphan have again portrayed themselves as patriots and defended their actions as being in the interests of the Cambodian people. Khieu Samphan, in an open letter in December 2003, admitted 'systematic killings', but in his 2004 book he claimed that he 'didn't know' about Tuol Sleng and had no power to stop the atrocities. ${ }^{40}$ At his trial, Nuon Chea expressed some remorse in terms of the failure of the revolution, but as in the past admitted only that the regime made some mistakes and placed the blame on the Vietnamese, ${ }^{41}$ thus somewhat ironically reinforcing the genocide ideology that justified their persecution under the Khmer Rouge. As PoKempner suggests, rather than creating a new respect for the rule of law in Cambodia, the opportunity taken by the former Khmer Rouge leaders during their trials to continue to justify their actions could have the opposite effect. ${ }^{42}$

It is unfashionable to argue that the ECCC may be successfully meeting its goals, especially in the wake of criticisms of corruption and cooption of the Cambodian half of the court to meeting the political priorities of the Cambodian government, and undermining the international investigators' attempts to bring other former Khmer Rouge leaders before the Court. However, based on evidence I collected during interviews in January-February 2009, and surveys conducted by the Documentation Center for Cambodia around the same time period, it is not necessarily clear that Cambodians would welcome a broadening of the cases under 
investigation. As one female survivor interviewed in Battambang suggested to me, using a Khmer idiom similar to the idea that it would be 'opening a can of worms'; there was fear in local communities that going beyond the five key leaders could destabilise Cambodian society. Another female survivor, also interviewed in Battambang, said she thought that there would be 'chaos in the community' if more were tried. Where might it end? With the trial of Hun Sen and others in the government who were associated with the crimes of the Khmer Rouge?

Of course, this conservative view could be seen as reflecting the control of the government over the population, as human rights advocates might argue, and therefore a position to be overridden in the interests of due process and the legal duty to prosecute. In other words, justice for the international community should prevail, a normative position reflecting the power and influence of the 'justice cascade'. ${ }^{43}$ On the other hand, concerns about expanding the number of trials could be interpreted as a legitimate reason for regarding the trial of only the key leaders as sufficient in terms of setting an example and providing a symbol of accountability and recognition of the suffering of Khmer people during the Pol Pot era.

Some of the Cambodians whom I interviewed in January-February 2009 indicated that they thought only the top leaders should be prosecuted because they recognized that many of the lower level former Khmer Rouge were not to blame, or they observed that there was reconciliation but not justice or accountability for the leaders who were responsible. For example, a male survivor from Kampong Thom, who was a youth at the time of the Khmer Rouge period, said: 'In my opinion it should be the top leaders [who are tried] as the lower rank officials were led by the top leaders'. He also said that he thought that the ECCC could bring reconciliation in the community. By contrast, others thought that more former Khmer Rouge should be prosecuted. For example, a male survivor who was 25 years old at the time of the Pol Pot regime whom I interviewed in Siem Reap said "I think not only those few should be tried ... more should be tried" and he also thought the KRT would not bring reconciliation.

But for the women living in Battambang quoted above, opening the trials to more former Khmer Rouge beyond the top five leaders was seen as a threat to peaee and stability. This position reflects a more pragmatic approach to transitional justice that responds to the perceptions and expressed needs of locally affected communities even when these views my seem to run counter to international human rights norms.

Cambodians also expressed legitimate concerns that Case 002 has not yet considered the charges of genocide, and that the accused may die before the second part of the trial. This concern highlights the problem of separating the charges; even though there is a greater chance of reaching a conviction for some of the crimes while the defendants are still alive, it also reduces the chances that the survivors will achieve any sense of justice in relation to the more serious crimes which generated the majority of their suffering. It also limits the opportunity for truth recovery and acknowledgement from the former Khmer Rouge leaders in relation to these crimes if the second mini-trial is postponed until after the findings are pronounced for the first minitrial. ${ }^{44}$

I argue that the symbolic potential of the ECCC should not be underestimated, however. As explained by a survivor whom I interviewed in Phnom Penh in October 1999: "We have to punish [the former Khmer Rouge] ... a matter of national responsibility ... biggest case of impunity in the world and the mother of other smaller impunities in Cambodia." Similarly in 2009, I interviewed Cambodians in a number of rural areas who had lost loved ones and suffered from the hardships during the Pol Pot era, who expressed relief that finally their suffering was receiving official acknowledgement by the international community and that they at last felt a sense of justice for what had happened to them. In commenting on his experience of the closing hearings of Case 002/01, Kranh Uth, an 82-year-old genocide survivor from Kandal Province, said: "In the KR regime, I lost 12 relatives. When I see the KR leaders in trial, my emotions seem not agitated anymore. The court is helping me to find what I have lost for all these years: justice and relief." ${ }^{45}$ Similarly, as quoted earlier, 60-year-old Kem Chem from Pursat Province referred to how the ECCC was providing 'a real reconciliation' and that when attending the court he felt like anger was released from his heart. Even if the former Khmer Rouge leaders in Case 002 continue to deny their culpability, the finding by the ECCC of individual guilt could provide a strong counter to this denial and the punishment meted out could go some may towards satisfying the calls for justice as well as contributing to healing and reconciliation.

The evidence suggests that a majority of ordinary Cambodians wanted a tribunal to be established. For example, in January 1999, 84,195 Cambodians signed a national petition calling for an international 
tribunal; 5000 Cambodians rallied in support of an international tribunal in Phnom Penh in August 1999; surveys conducted by the Khmer Journalists' Association in 1995 and the Institute of Statistics and Research on Cambodia (IFFRASORC) in 1999 both reported that 80\% of the population wanted the former Khmer Rouge leaders to be prosecuted; and a survey of 7000 Cambodians conducted by DC-Cam in 2002 found that $57 \%$ wanted 'the kind of accountability that only a tribunal could bring. ${ }^{46}$ Further evidence of support from ordinary Cambodians for a tribunal has also been provided by interviews and surveys conducted by this author and other researchers. ${ }^{47}$

In 2009, when I returned after ten years to further explore Cambodian attitudes now that the ECCC had been established and the first trial was finally beginning, I found the evidence of support was less clear amongst the general population. Young people who had not experienced the Pol Pot era were sceptical and critical, or simply not interested in the court and its proceedings. Older Cambodians who had fought with the Khmer Rouge because they believed in the mission to oust the Lon Nol government and rid the country of US influence, were concerned about the ramifications of their association with the Khmer Rouge being falsely linked to the perpetration of human rights violations rather than also being seen as victims of the period. This was especially the case in relation to children who were forcefully recruited to carry out the relocation and societal reordering mandated by the Pol Pot clique.

By contrast, however, many of the Cambodians I interviewed in January-February 2009 were extremely interested in following the ECCC proceedings and some were keen to participate as civil parties. I interviewed a number of older Cambodians, some of whom were still showing signs of the trauma they had suffered, who wanted to take advantage of the opportunity to participate in the outreach activities being conducted by the Documentation Center of Cambodia (DC-Cam) and a number of human rights and peace NGOs in rural areas, and to use the opportunity to educate their children about what happened during the Pol Pot era. ${ }^{48}$ Many young Cambodians had been impatient with their parents' unusual behavior such as hoarding food (presumably symptoms of trauma), had not believed their stories and were generally dismissive of the history of that era. A common refrain of older interviewees was that young people who were born after the Khmer Rouge era did not believe what had happened, and the observation that the ECCC would be helpful to educate young people so 'the next generation will not follow the same bad actions' (a female survivor interviewed in Kampong Thom who was a young woman during the Khmer Rouge period). A female survivor interviewed in Siem Reap mentioned that 'most children including my own are reluctant to believe'. She said that 'even though it happened a long time ago, I do not have peace in my mind ... when I sit down alone I recall past events and I cry'.

The local NGO, Youth for Peace, has been particularly active in rural communities bringing young people and older people together to learn from each other: the older generations explain about the Khmer Rouge period while the younger generations explain about the ECCC. ${ }^{49}$ Working in conjunction with the International Center for Conciliation, Youth for Peace found that participants experienced a greater sense of community and reduced social barriers..$^{50}$ In 2012, Youth for Peace inaugurated its first Community Peace Learning Center at a memorial site in Takeo province and it continues to play a leading role in furthering understanding of the Khmer Rouge period. ${ }^{51}$ DC-Cam, meanwhile, has led efforts to introduce a new school curriculum, which accurately portrays the history of the period, in addition to its key contribution to documentation of the genocide and support for victim participation in the trials at the ECCC.

Outreach is a critical yet often undervalued aspect of transitional justice, including in Cambodia where planning for outreach was inadequate in terms of political will, funding and institutional design. ${ }^{52}$ Outreach is necessary for justice to be served not only for the international community, but also for the local population by ensuring that they are informed and, where appropriate, able to participate in the trial proceedings. Thanks to the efforts primarily of civil society organizations, almost 4000 civil parties were registered in Case 002 and of these thirty-one gave evidence during the first mini-trial, and more than 100,000 members of the public attended the hearings. ${ }^{53}$

A parallel process, which can also enhance the effectiveness of transitional justice mechanisms such as the ECCC, is what I have called 'inreach' - obtaining ideas, opinions and feedback from local populations about their expectations and responses to the transitional justice process. ${ }^{54}$ This two-way communication or dialogue can, I argue, increase the experience of local ownership and contribute more meaningfully to peacebuilding and conflict transformation. During my field research in 2009 I observed how DC-Cam was assisting in this process of inreach by conducting a survey to ascertain public attitudes towards the expansion of the trials to cover more than the key leaders already accused in Case 001 and Case 002. 
Both those who had experienced the Khmer Rouge period and those who had not, showed a keen interest in seeing documentaries of former Khmer Rouge leaders shown at outreach sessions, and later being able to go the Court to see the former leaders facing trial. ${ }^{55}$ Hearing others talk publicly and on film about what they had suffered seemed to be providing a sense of validity for their own experiences. In short, the psychosocial benefits of the ECCC seemed to be outweighing any dangers of retraumatization by revisiting the horrors of the past. ${ }^{56} \mathrm{My}$ research provided evidence of the value of the ECCC for the psychological health of victims and survivors, as well as building family and community relations. For example, a female survivor I interviewed in Prey Veng spoke of feeling 'peace in [her] heart' for the first time because of the KRT, while a male village chief interviewed in Battambang said that he would feel 'peace in [his] mind' when there was a trial of Khieu Samphan. Others showed great interest in the court and seeing those who had perpetrated the crimes against them being tried and punished, and many said that they thought the ECCC would bring reconciliation as well as justice. A female survivor interviewed in Kampot who was 15 at the time of the Khmer Rouge said she thought the top leaders "should be tried because they were treating us very badly then and because of them I became an orphan" and that she felt happy because there is a trial.

My findings have been supported and qualified by the results of research by Holmes and Ramji-Nogales ${ }^{57}$ and Strasser et $\mathrm{a}^{58}$ who interviewed Cambodians in relation to their experiences of Case 001. Holmes and Ramji-Nogales found that victim participation in the ECCC can provide a form of reparative healing or transformative justice, ${ }^{59}$ but that this is limited because only a select few survivors of the Khmer Rouge regime are eligible to be civil parties. ${ }^{60}$ They observed that those who attended trials without being able to participate as civil parties were more likely to feel retraumatized and that without adequate psychosocial support, listening to the hearings might retard rather than promote healing. ${ }^{61}$ They also found that community dialogues supported by NGOs such as DC-Cam can 'begin the process of community-wide healing' in a way that can provide a more significant and lasting impact on reconciliation that the ECCC trials themselves. ${ }^{62}$

Strasser et al, meanwhile, concluded from their research in relation to Case 001 that some of the psychological dynamics of participating as civil parties were beneficial whilst others 'carry the risk of increasing victims' suffering. ${ }^{63}$ They observed that civil parties appreciated the educational and preventive benefits of participation, but that they found it very difficult and painful attending the criminal proceedings, hearing the testimonies and being reminded of their own and their relatives' suffering. Trial proceedings do not generally allow for the expression of 'emotional truth' and the rather 'dry and factual' way in which the evidence is heard does not allow survivors to access and better understand their 'individual and collective pain and suffering' in a way that can promote a healing or restorative truth, according to Strasser et al. ${ }^{64}$ They also speculate on how Duch's requests for forgiveness could harm victims psychologically, as such forgiveness could only be contemplated by victims after truth and justice. ${ }^{65}$ Overall though, despite these challenges, Strasser et al concluded, consistent with my earlier findings, that the psychological benefits outweighed the potential harmful effects on survivors in three primary ways: acknowledgement and condemnation; providing testimony; and psychological support services. ${ }^{66}$ They also emphasized the critical contribution of TPO in enabling civil parties to 'deal with stressful and controversial situations typical in a criminal proceeding. ${ }^{67}$

On the other hand, there is evidence that many Cambodians are unaware or uninterested in the ECCC and its proceedings, although this level of knowledge has increased since the trials began. ${ }^{68}$ According to the latest survey conducted by the Berkeley Human Rights Center in 2010, 75\% of Cambodians had a limited general knowledge about the ECCC, up from $61 \%$ in 2008. However, the researchers found little evidence of Cambodians with a detailed understanding of the Court. ${ }^{69}$ The limited outreach conducted by the ECCC to explain the capacity and functioning of the Court has made it difficult to manage expectations, which is undermining the impact of the justice achieved and has caused unnecessary distress for victims (for example, when their cases were rejected in Case 001). ${ }^{70}$

There is a need for a more comprehensive national support strategy to provide psychosocial assistance to foster individual and collective healing and reconciliation that goes beyond the impact of the ECCC. ${ }^{71}$ The socioeconomic stresses experienced by many Cambodians also serve to undermine their ability to cope with the psychosocial impact of their suffering/trauma under the Khmer Rouge with which they are being confronted during the ECCC proceedings, supporting arguments for a more holistic and transformative approach to political as well as socioeconomic and psychosocial justice. ${ }^{72}$

There are also questions about the amount of resources required for the ECCC and whether this would be better spent on socioeconomic development. Funding shortfalls have been a continuing impediment to the efficient functioning of the ECCC and therefore its ability to satisfy the expectations of victims and other 
Cambodians. The Court has faced at least two funding crises in late 2011 and again in February 2013 when it ran out of money and staff were not being paid. In October 2013, both Japan and the UK made significant new funding available for the international side of the Court following the Cambodian government's announcement of bridging funds to enable the national side to complete its work in $2013 .{ }^{73}$ But this still leaves uncertainty regarding funding for 2014 and the successful completion of Case 002.

\section{Justice for the Future?}

I have argued elsewhere that in order for transitional justice to be transformative it needs to address the multiple justice needs and priorities of local affected populations, to transform relationships as well as structures and institutions, and to focus on the future as well as justice for past human rights violations. ${ }^{74}$ In order to transform Cambodian society, therefore, a more holistic and future-oriented vision of justice is required than that provided by the ECCC, one that includes elements of restorative, socioeconomic, political and psychosocial justice in addition to retributive justice.

A model of transformative justice incorporates the need not only for justice for the past, but also justice in the future. The culture of impunity, which has prevailed in Cambodia, is about more than the failure to prosecute the former Khmer Rouge; it is also about the continuing lack of respect for the rule of law in a country which still operates politically on a patronage system where power is more important than the law. ${ }^{75}$ The ECCC is expected to contribute to the development of rule of law in Cambodia through its legacy program which will be important for assessing the value and impact of the ECCC on future law and order, peace and stability in Cambodia.

There have been mixed reactions so far to the Court's ability to meet expectations in terms of capacity building through the development of rule of law, infrastructure and training of Cambodian legal personnel. Technical transfer of knowledge and skills appears to be occurring on an individual level, but there is limited evidence that this is being transformed into systemic and procedural reform in the judicial system. The Court is demonstrating a model of fair trial proceedings, although this is being undermined to some extent by the continuing accusations of corruption and political interference, which fail to provide a good example for developing the rule of law in Cambodia. The Court's hybrid nature has led to internal conflict and affected the Court's credibility, which feeds into the likely legacy impact.

There are also those who have argued against the imposition of Western-style legal justice provided by the ECCC as being alien to Khmer culture. According to Harris, such imposition of foreign systems and universal norms of justice 'may be read by some sectors of Khmer society [those for whom to be Khmer is to be Buddhist] as an expression of contempt for their own traditions. ${ }^{76}$ Some Cambodians have responded by expressing the desire to return to a Khmer approach to counter the influences of outsiders, which have in the past betrayed and neglected the needs and rights of the Cambodian people. They reject the modernist enterprise which privileges the Western rule of law approach, arguing for a need to reassert Khmer identity imbued with confidence rather than fear of the outside invader.

PoKempner argues, by contrast, that the insistence of Cambodians on international standards for the ECCC, far from being culturally alien, is a natural response to demand that their sufferings be considered as significant as those of Rwandans and Bosnians who were afforded the full international legal standards of an international tribunal. ${ }^{77}$ This argument is consistent with my observations and interviews in 2009 , as well as my research in other cultural contexts where the impact of globalization and norm diffusion has led to calls for international criminal prosecutions of those accused of genocide and other mass human rights violations. Local culturally specific justice and reconciliation mechanisms may still be deemed appropriate, although not normally for the key leaders and most serious crimes. For example, a number of interviewees in 2009 mentioned the value of Buddhist philosophy for supporting reconciliation in Cambodia, although they had not experienced any specific reconciliation mechanisms in their local communities following the return of survivors and former low-level Khmer Rouge. At the same time, they were less enthusiastic about reconciliation with the former key leaders who had orchestrated the genocide, but rather considered that they should be held accountable and would, inevitably, suffer for what they had done.

According to PoKempner, what is needed in terms of societal transformation in Cambodia is the building of a new national identity, which repudiates the narrative of the past and reflects values of impartiality, legality and fairness. ${ }^{78}$ Thus, accompanying the legal trials with campaigns for public education, community dialogue and reconciliation could enhance the value of the ECCC, as a forum for reconstituting Khmer identity. McGrew similarly argues for the need to restore dignity, identity and belonging as part of justice and reconciliation efforts in Cambodia. ${ }^{79}$ 
My field research conducted in 2009 suggested that the civil society outreach efforts to support the ECCC were contributing to this identity transformation to only a limited degree, although in some instances the relationship-building included in some of these outreach activities appeared to be making a significant impact on promoting understanding and social transformation, at least at the community level, to overcome the legacies of genocide. Civil society programs have subsequently expanded, including the work of Youth for Peace in transforming mass killing sites into sites of remembrance and peace education, and DC-Cam's emphasis on community dialogues to complement its outreach (and inreach) programs in relation to the ECCC. Others are conducting Buddhist ceremonies and TPO is promoting culturally adapted psychosocial interventions. ${ }^{80} \mathrm{McGrew}$ proposes a "joint narrative approach" which could further complement the ECCC by providing opportunities for community dialogue between perpetrators and victims which could promote the compassion of Buddhism at the same time as satisfying the survivors' "needs and desires to know why Khmer killed Khmer". ${ }^{81}$

The ECCC seems to be having little impact, meanwhile, on the national political level of justice. Hun Sen and his government continue to rule Cambodia with little regard for human rights and the rule of law, and civil society continues to have minimal if any impact on government policies. As discussed earlier, the legacy of the ECCC has not so far had any significant impact on legal systems and experiences of justice. The governance and participation sector of peacebuilding has been left unaddressed since the UN-sponsored elections in 1993, and Cambodians do not expect that the government will respond to their needs and priorities. For example, a male survivor whom I interviewed in Phnom Penh in February 2009 said that the KRT was helping him to feel peace in his mind, but only at a low level because he was "influenced by politics". A male survivor whom I interviewed in Kampot said that "today we have corruption so powerful people can change the situation from black to white, or white to black". Transitional justice provided by the ECCC has not addressed the need for political justice in Cambodia.

Similarly, there are dissatisfactions that socioeconomic justice has not been sufficiently addressed. The reparations offered by the ECCC provide some sense of justice for past suffering and have the potential to contribute to community development, but they can do little to transform extreme social inequalities that continue to plague Cambodian society. The perception continues that while most survivors of the Khmer Rouge genocide live in poverty, the former Khmer Rouge leaders are relatively well-off economically. Even though they have been arrested and are being tried by the ECCC, the former key leaders are perceived to have better living conditions than most rural Cambodians. This continuing experience of relative deprivation, for some genocide survivors, undermines any sense of peace, justice or healing they might otherwise feel as a result of the Khmer Rouge Tribunal.

Finally, the focus on documentation of mass human rights violations through DC-Cam and criminal accountability of high level Khmer Rouge leaders through the ECCC does not address the structural and other root causes of the genocide, nor does it deal with the need for justice in relation to the many lower level Khmer Rouge perpetrators. This paper has argued for the strengthening of psychosocial interventions and promotion of reconciliation as an appropriate means of addressing the lack of justice for the mass of lower level Khmer Rouge cadre who often also perceive themselves as victims. The current approach also does not allow for truth recovery and justice in relation to the United States and its bombing of Cambodia during the Vietnam War and contribution to the ease with which Pol Pot was able to gain popular support for his revolutionary movement to oust the pro-US Lon Nol government. The policies of the US and other foreign powers helped to create the structural context, which enabled Pol Pot to carry out his revolutionary genocide. Addressing these root causes through the truth-telling functions of a truth and reconciliation commission could support a more transformative justice process and outcome in Cambodia by allowing more crimes to be addressed, as well as wider participation and access to more healing or emotional truth than is possible with the ECCC. The benefits would, as with the ECCC, be dependent on the provision of sufficient psychosocial support to assist survivors to deal with the process and reduce the chances of retraumatization.

\section{Conclusion}

After more than 30 years, the ECCC is conducting trials of some of the key former Khmer Rouge leaders, marking an important step in ending the culture of impunity in Cambodia. However, despite evidence of public support for the establishment of the tribunal, it seems unlikely that the ECCC will be able to meet all of the expectations of the Cambodian people. From my field research in 1999, I concluded that Cambodians needed to know what happened during the Pol Pot era and why, and they needed acknowledgement from former 
Khmer Rouge leaders that what they did was wrong. Ten years later, my research revealed that these needs remained unfulfilled. Whilst the ECCC has subsequently provided some justice in the form of international acknowledgement and punishment for the perpetrators, which is arguably better than none, it has so far not answered the most important question of why the genocide occurred. Whilst Duch confessed and apologized repeatedly for his crimes in relation to S-21, the senior leaders who orchestrated the genocide being tried in Case 002, Nuon Chea and Khieu Samphan, only belatedly expressed some qualified regrets whilst at the same time continuing to maintain their innocence. Both leaders claimed ignorance and lack of responsibility for the atrocities, which occurred, and defended their actions as being driven by the need to rebuild the nation in the face of foreign threats and interference.

It is therefore questionable the extent to which genocide survivors will feel a sense of justice and satisfaction from Case 002, and even more so given the increasing likelihood that the two aging defendants could die before the trial is completed and the convictions recorded. On the other hand, at the time of the first trial, I found evidence that on a personal, psychosocial level, the ECCC was arguably worthwhile in terms of providing a sense of justice and peace for at least some survivors. I was less optimistic before I conducted my field research in 2009, and to some extent surprised by the feelings of inner peace and reconciliation that were being promoted because of the court's existence. My observations were consistent with the findings of other subsequent research that the psychological benefits of civil party participation in Case 001 outweighed the risks of retraumatization, at least when sufficient psychosocial support was also provided. The symbolic value of Case 002 should not be underestimated, either, as Cambodians see their former leaders being subjected to trial and imprisonment, suggesting that possibly some justice, however flawed, may be better than none.

The ECCC is nevertheless limited in its ability to fully satisfy the needs of justice for the Cambodian people and the international community, especially given the challenges of funding, high profile resignations, allegations of corruption and political interference, and slow progress. A greater emphasis on outreach and inreach could assist in improving the effectiveness of the Court, even within the constraints outlined in this paper. Even though justice through the ECCC is an important goal, retributive justice only for key individuals through a tribunal without truth and acknowledgement is only partial justice. The Court is unable to address the structural causes of the genocide, and unlikely to end the prevailing culture of impunity without a more constructive engagement with the Cambodian government in order to foster the rule of law throughout the country. Ending the bigger impunity is not necessarily contributing to ending all the smaller impunities in Cambodian society. This research suggests that other types of justice are also needed, including political and socioeconomic justice, in addition to an increased emphasis on psychosocial interventions, for Cambodians to fully benefit from the ECCC and to strengthen its contribution to long term recovery from genocide and ongoing peace and stability in the country.

\section{End Notes}

1. Impunity is the blatant, widespread lack of consequences or punishment for crimes or other wrongful acts.

2. Cambodian Human Rights Action Committee Statement, "CHRAC Demands Investigation into Violent Crackdown Against SL-Garment Factory Workers", 12 November 2013.

3. In October 1999 I interviewed twenty-two survivors and descendants of survivors of the Cambodian genocide living in the capital, Phnom Penh, as well as seven NGO and UN workers. In 2009 I returned to Cambodia and conducted interviews with a total of thirty-two survivors and former Khmer Rouge in Phnom Penh and six rural locations: Kampong Thom, Battambang, Prey Veng, Anlong Veng, Kampot and Kompong Speu. I also interviewed three staff at the ECCC, eight NGO representatives in Phnom Penh (including several members of CHRAC), attended three outreach sessions run by ADHOC and DC-Cam in rural areas, and the first day of Duch's trial at the ECCC in February 2009. Comments based on these semi-structured interviews should not be taken as representative of the views of the whole population, but should be seen as indicating the views of some individual Cambodians who can provide an insight into responses to the ECCC and other aspects of transitional justice by different sectors of the general population and the non-government sector.

4. For further details on Cambodian history and the genocide, see David Chandler A History of Cambodia, $2^{\text {nd }}$ edn. (Boulder, CO: Westview Press, 1996) and Ben Kiernan, The Pol Pot Regime: Race, Power, and Genocide in Cambodia under the Khmer Rouge, 1975-79 (New Haven, Connecticut: Yale University Press, 1996).

5. Ben Kiernan, 'The Cambodian Genocide - 1975-1979' in Samuel Totten, William S. Parsons \& Israel W. Charny (eds), Century of Genocide: Eyewitness Accounts and Critical Views (New York \& London: Garland Publishing, 1997) 343.

6. Kiernan, 1994, 191

7. Chandler, 1996, 214-215. The four-year plan referred to the need to "abolish illiteracy among the population" but primary schooling was limited, and education beyond the primary level was not available until 1978. The killing of former teachers regarded as "class enemies" was not a policy consistent with the education of the masses. 
8. See Kiernan 1997, 340-345 for statistical details of the minority groups targeted and the impact of the genocide on these groups.

9. Wendy R. Lambourne, Justice and Reconciliation: Post-Conflict Peacebuilding in Cambodia and Rwanda, PhD Thesis, University of Sydney, 2002; Kiernan 1997.

10. Etcheson provides a thorough analysis of the various attempts at redress or justice over the first 20 years following the fall of the Pol Pot regime, including attempts to instigate a case at the International Court of Justice; a Cambodian lustration law adopted in 1994; various US actions including adoption of the Cambodian Genocide Justice Act also in 1994; and efforts to establish a truth commission in 1996-97. See also Fawthrop and Jarvis (2005) who include an account of the Australian initiative in 1986 to pursue international legal accountability for the genocide in Cambodia which was ultimately quashed by political pressure from the US as well as resistance from ASEAN and China. Craig Etcheson, After the Killing Fields: Lessons from the Cambodian Genocide (Westport, CT: Praeger Publishers: 2005), 77-82.

11. Michael Vickery \& Naomi Roht-Arriaza, 'Human Rights in Cambodia' in Naomi. Roht-Arriaza (ed.) Impunity and Human Rights in International Law and Practice (New York: Oxford University Press, 1995) 246; Stephen P. Marks, "Elusive Justice for the Victims of the Khmer Rouge", Journal of International Affairs, 52:2, Spring 1999, 691-718. Etcheson 2005: 14-17.

12. Peter J. Hammer \& Tara Urs, 'The Elusive Face of Cambodian Justice', in Jaya Ramji and Beth Van Schaack (eds) Bringing the Khmer Rouge to Justice: Prosecuting Mass Violence Before the Cambodian Courts (Lewiston, NY: Edwin Mellen Press, 2005) 26.

13. The Khmer Rouge subsequently withdrew from the peace process and elections.

14. Hammer \& Urs, 2005.

15. Etcheson (2004: 182). Etcheson further documents the politics of genocide justice for the Khmer Rouge (2005: 141-66) and lists the reasons for the failure of the Cambodian government and international actors to end Khmer Rouge impunity (2005: 137-8).

16. “Charges Filed Against Ta Mok”, South China Morning Post, 10 March 1999; "Khmer Rouge Genocide Charge”, The Australian, 10 September 1999, 8.

17. For profiles of the former Khmer Rouge leaders see Fawthrop and Jarvis (2005: 254-69).

18. For an overview of the negotiations to establish the tribunal, see Wendy Lambourne, "The Khmer Rouge Tribunal: Justice for Genocide in Cambodia", refereed proceedings published online, Whither Human Rights, $25^{\text {th }}$ Annual LSAANZ International Conference, University of Sydney, 10-12 December 2008.

19. Tom Fawthrop \& Helen Jarvis, Getting Away with Genocide? Elusive Justice and the Khmer Rouge Tribunal (Sydney: UNSW Press, 2005). For a detailed account of the structure and functioning of the ECCC, see also John D. Ciorciari (ed.) The Khmer Rouge Tribunal, Phnom Penh: Documentation Center of Cambodia, 2006.

20. For an account of civil society participation in the ECCC see Christoph Sperfeldt, 'Cambodian Civil Society and the Khmer Rouge Tribunal', International Journal of Transitional Justice, 6, 2012, 149-160.

21. The Court Report, Issue 48, May 2012, 2.

22. Open Society Justice Initiative, "Planning and Leadership Now Needed at ECCC", Position Paper, November 2013.

23. Youk Chhang quoted in Robert Carmichael, "Cambodian Tribunal Ends First Trial in Key Khmer Rouge Case", Voice of America, 31 October 2013.

24. Justine Drennan, "Devil's Advocates at the Khmer Rouge Trial”, The Huffington Post, 15 November 2013.

25. The Court Report, Issue 66, November 2013, 4.

26. Long Panhavuth, of the Open Social Justice Initiative in Cambodia, quoted in Robert Carmichael, "Cambodians await justice in Khmer Rouge trial", Deutsche Welle, 15 October 2013; Harvard researchers Patrick Vinck and Phuong Pham quoted in Alvin Powell, "A thirst for justice delayed: Researchers explore Cambodian attitudes towards Khmer Rouge trials", Harvard Gazette, 9 April 2013.

27. The Court Report, Issue 66, November 2013, 5.

28. Justine Drennan, “Cambodia’s aging Khmer Rouge leaders issue final defense, deny genocide charges”, Associated Press, 31 October 2013. Note: Case 002/01 did not include charges of genocide against the accused.

29. Drennan, 31 October 2013.

30. Carmichael, 31 October 2013; Lauren Crothers, "As Trial Ends, KR Defendants Defiant to the Very Last", Cambodia Daily, 1 November 2013, 1.

31. Crothers, 2013.

32. "Reparation projects", The Court Report, Issue 66, November 2013, 3; "Meaningful reparation for Khmer Rouge victims", ECCC website, http://www.eccc.gov.kh, posted 25 February 2014, accessed 28 February 2014.

33. Toni Holmes \& Jaya Ramji-Nogales, 'Participation as Reparations: The ECCC and Healing in Cambodia' in Beth Van Schaak, Daryn Reicherter \& Youk Chhang (eds), Cambodia's Hidden Scars: Trauma Psychology in the Wake of the Khmer Rouge (Phnom Penh: Documentation Center of Cambodia, 2011), 172-188.

34. The Court Report, Issue 69, February 2014, 6. This follows criticism of the ECCC's approach to reparations in a Berkeley research report, Victims' Right to Remedy: Awarding Meaningful Reparations at the ECCC, published in November 2011. 
35. Dinah PoKempner 'The Tribunal and Cambodia’s Transition to a Culture of Accountability', in Jaya Ramji \& Beth Van Schaack (eds) Bringing the Khmer Rouge to Justice: Prosecuting Mass Violence Before the Cambodian Courts (Lewiston, NY: Edwin Mellen Press, 2005) 333-358.

36. E. E. Meijer, "The Extraordinary Chambers in the Courts of Cambodia for Prosecuting Crimes Committed by the Khmer Rouge: Jurisdiction, Organization, and Procedure of an Internationalized National Tribunal" in C. P. R. Romano, A. Nollkaemper and J. K. Kleffner (eds) Internationalized Criminal Courts: Sierra Leone, East Timor, Kosovo, and Cambodia, Oxford, UK: Oxford University Press, 2004) 214.

37. As argued by supporters of King Sihanouk, according to Youk Chhang, "Why the Khmer Rouge Tribunal Matters to the Cambodian Community: Justice for the Future, Not the Victims", Phnom Penh: Documentation Center of Cambodia.

38. Dr Kek Galabru, President, LICADHO (Cambodian League for the Promotion and Defense of Human Rights), as quoted in "Cambodians talk about the Khmer Rouge trial", Phnom Penh Post, 4-17 February 2000, 12.

39. Peter Maguire, Facing Death in Cambodia (New York, NY: Columbia University Press, 2005) 192-3.

40. Fawthrop \& Jarvis 2005: 250

41. Maguire 2005:192

42. PoKempner 2005: 352-3.

43. Kathryn Sikkink, The Justice Cascade: How Human Rights Prosecutions are Changing World Politics (New York: W. W. Norton, 2011).

44. The ECCC Trial Chamber is continuing to work towards delivery of the verdict in Case 002/01 in the second quarter of 2014, whilst at the same time preparing for the substantive hearing of Case 002/02, The Court Report, Issue 69, February 2014, 4.

45. The Court Report, Issue 66, November 2013, 5.

46. Youk Chhang, 'The Thief of History - Cambodia and the Special Court', International Journal of Transitional Justice, 2007, 1, 171.

47. Lambourne 2002; Jaya Ramji, "Reclaiming Cambodian History: The Case for a Truth Commission”, Draft paper and survey results supplied by the author, April 1999; Laura McGrew, "Truth, Justice, Reconciliation and Peace in Cambodia: 20 Years After the Khmer Rouge", Paper presented to the Canadian Peace Research and Education Association 2000 Conference, Kingston, Ontario, 3 June 2000; William W. Burke-White, "Preferences Matter: Conversations with Cambodians on the Prosecution of the Khmer Rouge Leadership" in Jaya Ramji \& Beth Van Schaack (eds) Bringing the Khmer Rouge to Justice: Prosecuting Mass Violence Before the Cambodian Courts (Lewiston, NY: Edwin Mellen Press, 2005) 97-125.

48. For further details about the outreach activities conducted by Cambodian NGOs and the ECCC see Wendy Lambourne, "Outreach, Inreach and Civil Society Participation in Transitional Justice" in Nicola Palmer, Phil Clark \& Danielle Granville (eds) Critical Perspectives in Transitional Justice (Cambridge, UK: Intersentia, 2012) 235-261.

49. Interviews conducted by the author with Youth for Peace in February 2009.

50. Johanna Herman, "Peacebuilding and Transitional Justice in Cambodia: Attempts at DDR and the rise of victim-centred justice" in Chandra Lekha Sriram, Jemima Garcia-Godos, Johanna Herman \& Olga Martin-Otega (eds), Transitional Justice and Peacebuilding on the Ground: Victims and ex-combatants, (London/New York: Routledge, 2013), 116.

51. "Youth for Peace opens first Peace Learning Center", The Court Report, Issue 48, May 2012, 4.

52. Sperfeldt, 2012.

53. Extraordinary Chambers in the Courts of Cambodia, Press Release, "Closing Statements in Case 002/01 Concludes", 31 October 2013.

54. Lambourne 2012.

55. Observations during field research conducted in Phnom Penh and six rural locations in Cambodia in January-February 2009, including interviews with representatives of KID, ADHOC, CSD, YFP, DC-Cam, CHRAC and ECCC. Whilst the ECCC assisted in bringing members of the public to the Court to observe the trials, the NGOs were responsible for the majority of outreach and support for victims to participate in the proceedings. Criticisms have been made of the low priority and resources invested in outreach by the Court, the lack of legal aid and strategic coordination with civil society. Given diminishing interest from international donors, not only in funding the Court but also NGO programs, it is unlikely that support for civil parties will be sustainable for the continuation of Case 002. Sperfeldt, 2012; Lambourne 2012.

56. The NGO Transcultural Psychosocial Organization (TPO) has played a significant role in assisting the Victims Support Section of the ECCC by conducting trainings and providing psychosocial support for victims during the court proceedings, which has contributed to the avoidance of retraumatization.

57. Holmes \& Ramji-Nogales, "Participation as Reparations", 2011.

58. Judith Strasser, Julian Poluda, Chhim Sotheara \& Phuong Pham, "Justice and Healing at the Khmer Rouge Tribunal: The Psychological Impact of Civil Party Participation", in Beth Van Schaak, Daryn Reicherter \& Youk Chhang (eds), Cambodia's Hidden Scars: Trauma Psychology in the Wake of the Khmer Rouge (Phnom Penh: Documentation Center of Cambodia, 2011), 149-170.

59. See further discussion of the concept of transformative justice in Wendy Lambourne, 'Transitional Justice and Peacebuilding After Mass Violence', International Journal of Transitional Justice, 3:1, March 2009, pp. 28-48. 
60. Holmes \& Ramji-Nogales, "Participation as Reparations", 2011.

61. Holmes \& Ramji-Nogales, "Participation as Reparations", 2011, 180.

62. Holmes \& Ramji-Nogales, "Participation as Reparations", 2011, 181. By contrast, Joel Brinkley reported the observations of psychiatrists and others working in Cambodia that the outreach sessions run by DC-Cam were irresponsibly re-opening wounds and risking the mental and physical health of participants by failing to provide follow-up support. Joel Brinkley, Cambodia's Curse: The Modern History of a Troubled Land, (Melbourne: Black Inc, 2011), 326-330.

63. Strasser et al, 2011, 151.

64. Strasser et al, "Justice and Healing at the Khmer Rouge Tribunal”, 2011, 159.

65. Strasser et al, "Justice and Healing at the Khmer Rouge Tribunal", 2011, 160.

66. Strasser et al, "Justice and Healing at the Khmer Rouge Tribunal", 2011, 161.

67. Strasser et al, "Justice and Healing at the Khmer Rouge Tribunal", 2011, 164.

68. Phuong Pham et al, So We Will Never Forget, Human Rights Center, University of California, Berkeley, January 2009; Phuong Pham et al, After the First Trial, Human Rights Center, University of California, Berkeley, June 2011.

69. Pham et al, 2009; Pham et al, 2011.

70. Transcultural Psychosocial Organization report. TPO has been studying the psychological impact on civil parties of the ECCC process. Strasser et al "Justice and Healing at the Khmer Rouge Tribunal", 2011.

71. Strasser et al, "Justice and Healing at the Khmer Rouge Tribunal”, 2011, 166.

72. Strasser et al, "Justice and Healing at the Khmer Rouge Tribunal", 2011, 167; Lambourne 2009.

73. The Court Report, Issue 66, November 2013, 7.

74. Lambourne 2009.

75. PoKempner 2005: 339.

76. Ian Harris, “Onslaught on Beings': A Theravada Buddhist Perspective on Accountability for Crimes Committed in the Democratic Kampuchea Period" in Jaya Ramji and Beth Van Schaack (eds) Bringing the Khmer Rouge to Justice: Prosecuting Mass Violence Before the Cambodian Courts (Lewiston, NY: Edwin Mellen Press, 2005) 80.

77. PoKempner (2005: 354)

78. PoKempner 2005: 353

79. Laura McGrew, "Pathways to Reconciliation in Cambodia", Peace Review, 23:4, 2012, 514-521.

80. The Court Report, May 2012; Sperfeldt 2012, 157.

81. McGrew, 2012, 518. 